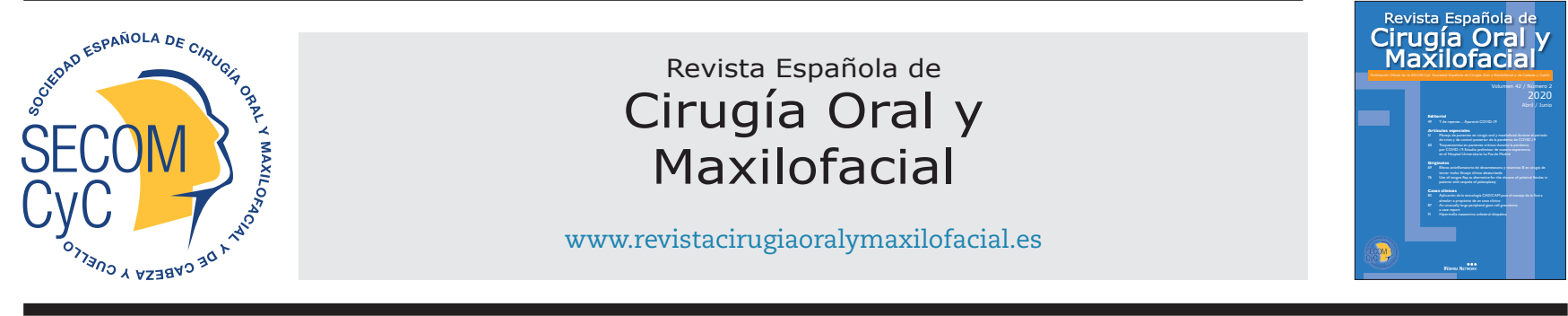

\title{
Original
}

\section{Use of tongue flap as alternative for the closure of palatinal fistulas in patients with sequela of palatoplasty}

\author{
Dionelys Barazarte, Rubén Muñoz, José Golaszewski, Bricelys Pulgar, Leober Moro and \\ Andrea Maldonado
}

Oral and Maxilofacial Surgeon, "Dr. Angel Larralde” University Hospital. Carabobo University, Venezuela

INFORMACIÓN DEL ARTÍCULO

Historia del artículo:

Received: october 15, 2019

Accepted: april 6, 2020

\section{Keywords:}

Palatal fistulas, flap, tongue flap, oronasal communication.

\section{A B S T R A C T}

\begin{abstract}
Aims: A retrospective study was conducted in the Department of Oral and Maxillofacial Surgery Dr. Atilio Perdomo; Ángel Larralde Hospital, Carabobo- Venezuela, which describes the procedure and protocol of the postoperative period of patients operated on multiple occasions for the closure of palatal fistulas.

Material and methods: A total of 20 patients treated for palatal fistulas were included in this study, in the period between 2014-2018. Patients with presence of sequelae of palatal fistulas, large fistulas with inadequate local scars, presence of oronasal communication and hypernasal resonance were considered. Patients were evaluated during the first 24 hours, 21 days and 6 months.

Results: A total of 20 patients (12 men and 8 women) with palatal fistulas were treated with tongue flap, aged between 25 and 40 years. In the postoperative period, patients reported $58 \%$ of cases, mild pain. The most frequent clinical signs during the postoperative period were presented in $60 \%$ of the patients, showing headache, passive bleeding, severe pain. No significant changes in lingual motility. Acoustic analysis of the 6-month late postoperative control voice, presented favorable changes in the intonation line, showing its continuity. All remaining cases showed satisfactory cure, and donor site morbidity was minimal.

Conclusions: The tongue flaps are an excellent alternative for closing large or recurrent palatal fistulas, due to their versatility and excellent vascularity of the area. However, the design and the delicate manipulation of the flap are also decisive.
\end{abstract}

\footnotetext{
*Autor para correspondencia:

Correo electrónico: dionelysb@gmail.com (Dionelys Barazarte). 


\section{Uso del colgajo de lengua como alternativa para el cierre de las fístulas palatinas en pacientes con secuela de palatoplastia}

\section{R E S U M E N}

Palabras clave:

Fístulas palatinas, colgajo, colgajo de lengua, comunicación oronasal.
Objetivos: Se realizó un estudio retrospectivo en el Departamento de Cirugía Oral y Maxilofacial Dr. Atilio Perdomo, Hospital Ángel Larralde, Carabobo- Venezuela, que describe el procedimiento y protocolo del postoperatorio de pacientes operados en múltiples oportunidades para el cierre de fístulas palatales.

Material y métodos: Se incluyeron en este estudio un total de 20 pacientes tratados por fístulas palatinas, en el periodo comprendido entre 2014 y 2018. Se consideraron secuelas de fístulas palatinas, las fístulas grandes con cicatrices locales inadecuadas, la presencia de comunicación oronasal y resonancia hipernasales. Los pacientes fueron evaluados durante las primeras 24 horas, 21 días y 6 meses.

Resultados: Un total de 20 pacientes (12 hombres y 8 mujeres) con fístulas palatales fueron tratados con colgajo de lengua, con edades entre 25 y 40 años. En el postoperatorio, los pacientes informaron el 60 \% de los casos, dolor leve. Los signos clínicos más frecuentes durante el postoperatorio se presentaron en el $60 \%$ de los pacientes, con cefalea, sangrado pasivo y dolor intenso. No hay cambios significativos en la motilidad lingual. El análisis acústico de la voz de control postoperatorio tardío de 6 meses presentó cambios favorables en la línea de entonación mostrando su continuidad. Todos los casos restantes mostraron una cura satisfactoria, y la morbilidad del sitio donante fue mínima.

Conclusiones: Los colgajos de lengua son una excelente alternativa para el cierre de fístulas palatinas grandes o recurrentes debido a su versatilidad y excelente vascularización del área, lo que brinda una gran seguridad al cirujano en el éxito del tratamiento, sin embargo, el diseño y la delicada manipulación del colgajo también son determinantes.

\section{INTRODUCTION}

The reconstruction of the defects of the oral cavity in patients diagnosed with palatal clefts is a challenge for the surgeon, since the most frequent complication (with a recurrence rate of $3.4 \%$ to $15 \% \%^{1,2}$ after the repair of the cleft palate) is the palatal fistula throughout the world. It is defined as abnormal communication between the oral cavity and the nasal cavity. The size of these fistulas varies from small $(<2 \mathrm{~mm})$, medium $(2-5 \mathrm{~mm})$, or large $(>5 \mathrm{~mm})$ wide $^{3,4}$. Technically, it is difficult and challenging to close them due to the shortage of local tissue for closure, as well as an excess of fibrosis and scarring in the palatal region as a result of previous surgeries.

There are different alternatives and techniques for the closure of palatal fistulas according to size and location, among which the local intraoral flaps include the flap of the palatal island, the buccinator myomucosal flap, the oral fat flap (Bichat adipose ball), flap of the tongue, temporary muscle flap. The flap of the tongue has become a very versatile flap since it is an excellent donor site for the oral reconstruction of soft tissues, mainly due to its abundant vascularity, its flexible nature and low morbidity associated with its use.

Eiselsberg in 1901, was one of the first to use pedicled lingual flaps to repair intraoral defects ${ }^{5}$. Lexer reported the use of a pedicled tongue flap with a posterior base in the management of retromolar and tonsil defects in $1909^{6}$. Later, in 1956, Klopp and Schurter described the use of a flap on the tongue to repair a soft palate defect ${ }^{7}$. In 1966, Guerrero-Santos and Altamirano introduced the dorsal tongue flap with anterior base for the surgical closure of a large palatal fistula, popularizing this technique ${ }^{8}$. In 1972, Cadenat et al. described the rich submucosal vascular plexus in the tongue and showed that tongue flaps can be lifted safely in any direction, even when they are only $3 \mathrm{~mm}$ thick .

In this article, the intraoperative procedure is presented and described, as well as the precautionary protocol in the postoperative period of patients operated on multiple opportunities for the closure of palatal fistulas and the prevention of complications and detachment of the flap.

\section{MATERIALS AND METHOD}

A retrospective study was performed at the Oral and Maxillofacial Surgery Department Dr. Atilio Perdomo; Ángel Larralde Hospital, Carabobo- Venezuela, where 20 patients (12 Male-8 Female) were studied with a sequela of closure of palatal fistulas, in ages between 25 and 40 years old that attended in the period between 2014-2018. Took into account as inclusion criteria: Patients with anterior palatal fistulas that had not previously been able to close (sequelae), large fistulas with inadequate local scars, presence of oronasal communication, fluid regurgitation and hypernasal resonance, ages between 25 and 40 years. We excluded patients who were not suitable for general anesthesia due to systemic conditions, small defects that can be closed with local flaps.

An intraoral examination is performed to assess and measure the fistula, evaluation at the time of food intake, in the same way the Cone Beam tomography was performed to 


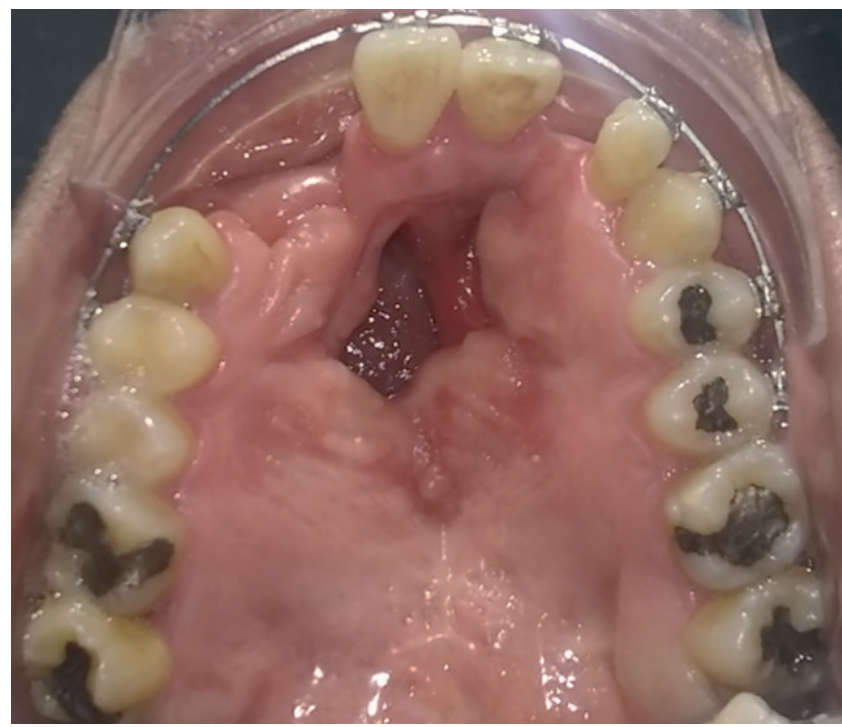

Figure 1. Palate fistula.

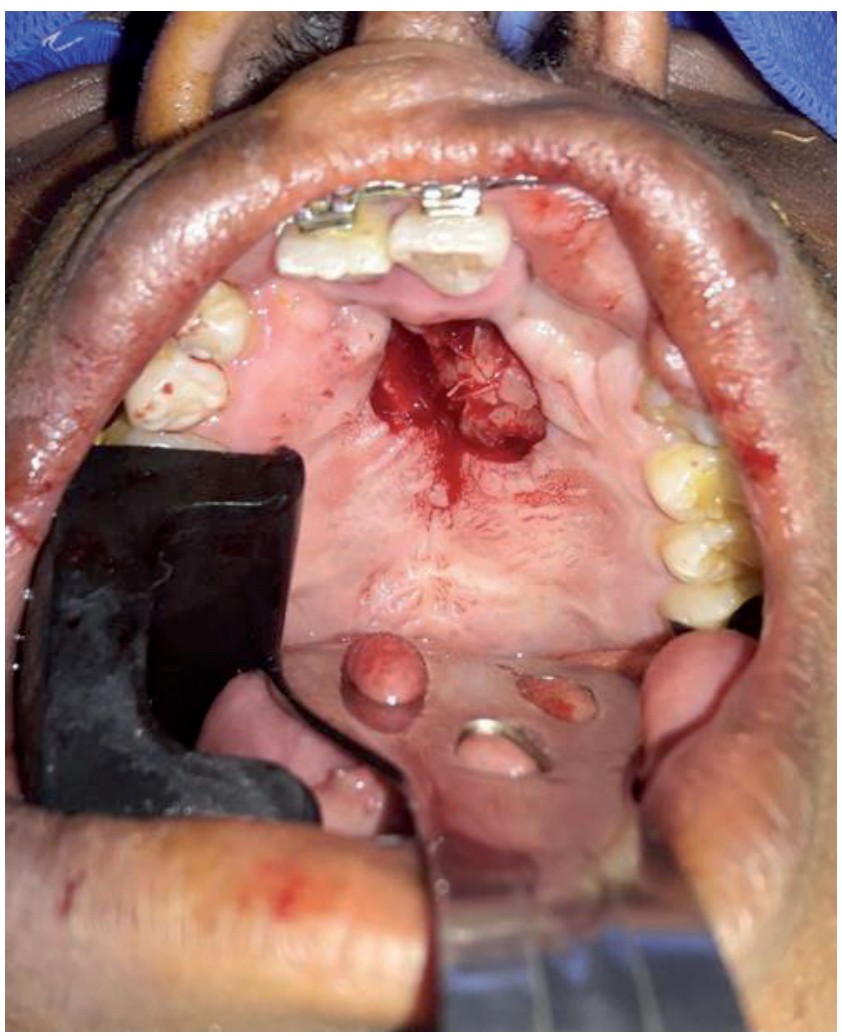

Figure 2. Peripheral incision in the edges of the fistula.

corroborate the defect, the use of PRAAT software for appreciation of hypernasal resonance, Lingual motility, deep and superficial sensitivity and the sense of taste of each patient are evaluated. The maxillofacial clinical examination shows patients with defects from $9 \mathrm{~mm}$ wide $\mathrm{x} 14 \mathrm{~mm}$ long approximately, in the anterior part of the hard palate, with diffuse borders, normochromic mucosa and hydrated in said region (Figure 1). Cone Beam tomography showed an isodense im-

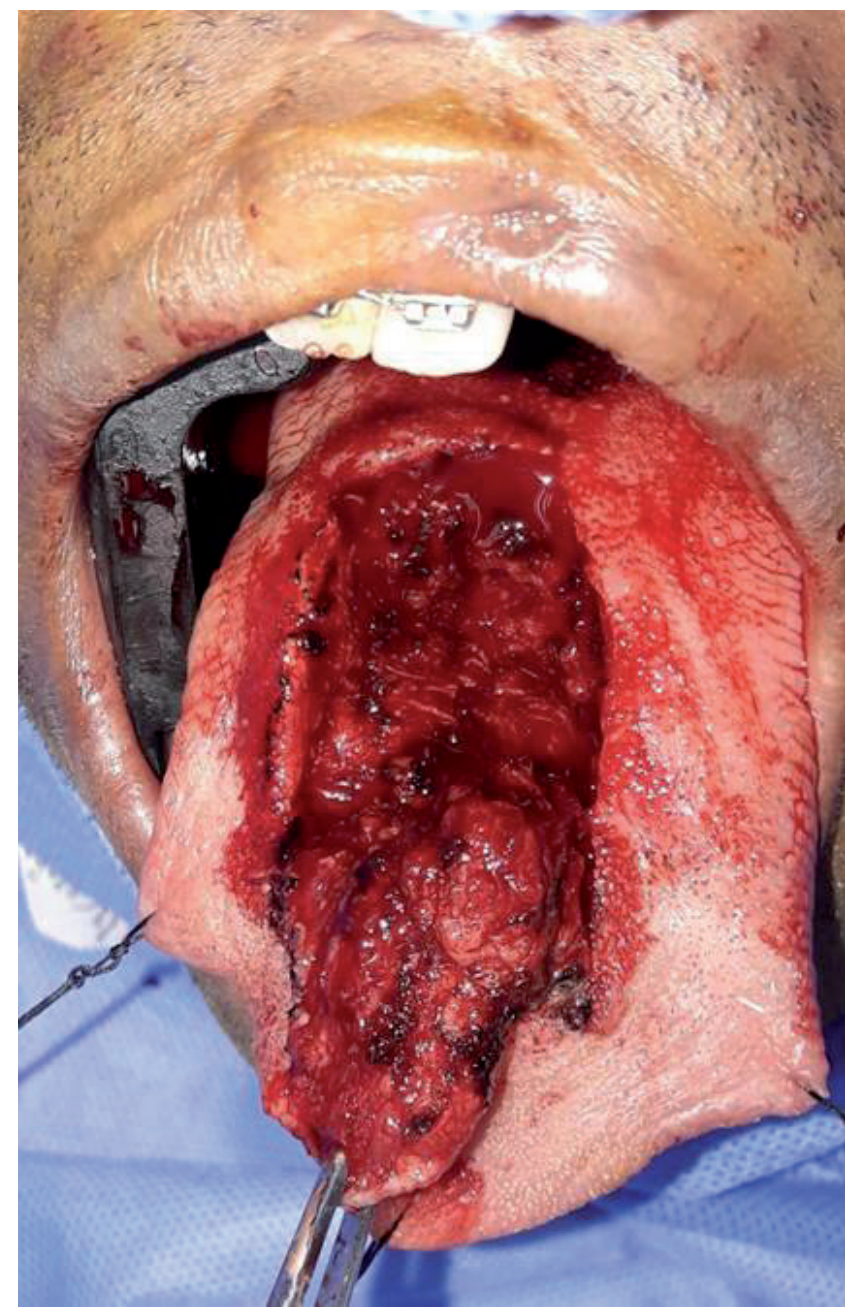

Figure 3. Flap of the tongue.

age in the anterior palatal region which extends to the nasal cavity.

Under general anesthesia and nasotracheal intubation, infiltration of $2 \%$ lidocaine with epinephrine 1: 80,000 in anterior palatal defect is performed. The surgical technique used was as follows ${ }^{10}$ : A peripheral incision was made in the edges of the fistula, with scalpel blade \# 15, the margins of the defect were carefully dissected, the margins of the incision were inverted, faced without tension and sutured with 4.0 resorbable suture so that the mucosal plane was formed (Figure 2). A 3.0 silk suture was placed on the tip of the tongue to be able to perform the traction and exposure of the dorsal aspect. The design-was made to ensure that the size of the flap did not exceed the two thirds of the width of the tongue and the circumvallate papilla or the tip of the tongue to avoid compromising it.

A $2 \%$ lidocaine anesthetic solution was infiltrated with 1 : 80,000 epinephrine at the donor site. The flap of the tongue was lifted with $5 \mathrm{~mm}$ of muscle to ensure a better blood supply and healing (Figure 3). The flap rested on the fistula with the space of the nasal layer in the center of the tip of the flap; this results in a 2-layer closure at the periphery of the fistula. Tissue synthesis is performed firstly in the nasal mucosa with 
a 4.0 resorbable suture and later a 3.0 resorbable suture was used, using simple points to fix the flap of the tongue to the nasal layer and the mucosa of the palate by mouth (Figure 4).

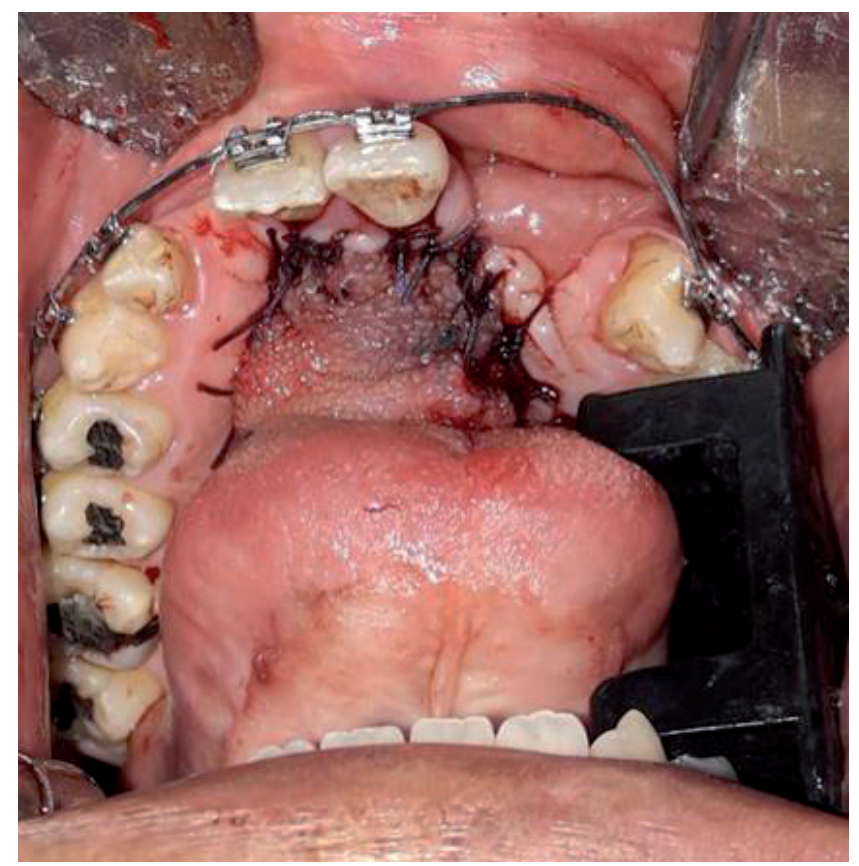

Figure 4. Closure at the periphery of the fistula and the flap of the tongue to the nasal layer and the mucosa of the palate.

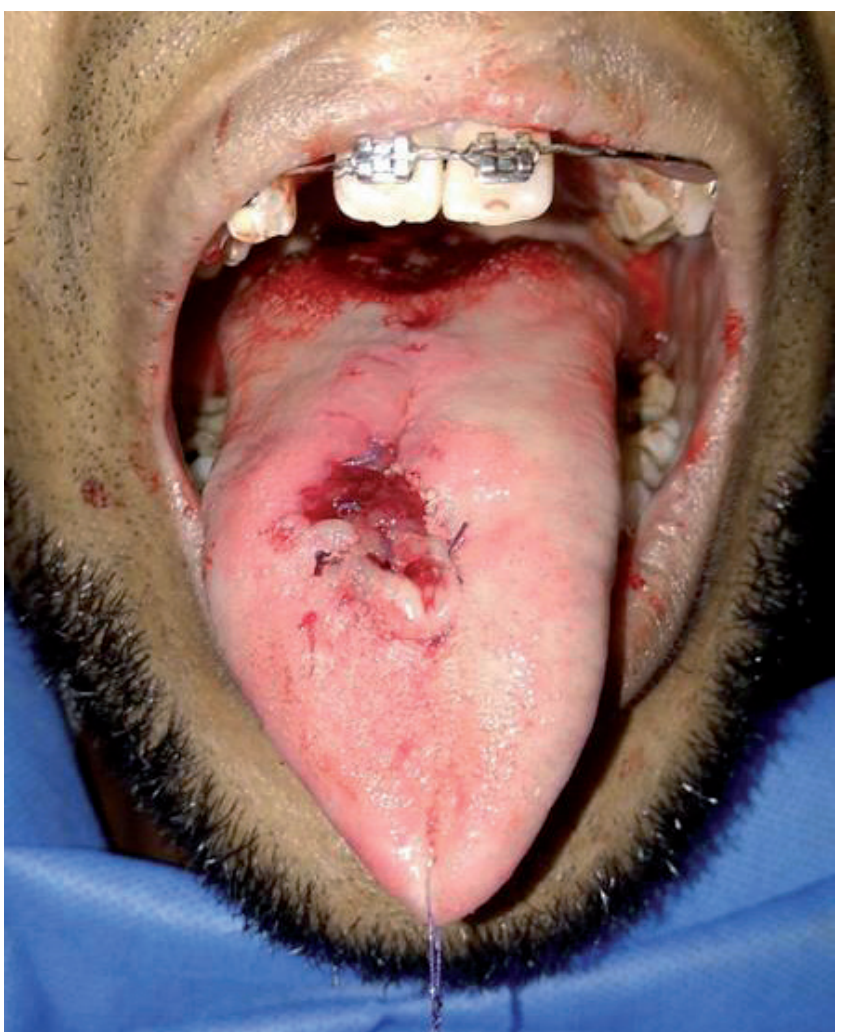

Figure 5. Donor site closure with suture.
The donor site of the tongue was closed with 3.0 resorbable suture with mattress points after a meticulous hemostasis (Figure 5).

Patients were observed for 24 hours; they did not merit maxillomandibular fixation. After a period of healing and adequate healing of 21 days, the pedicle was sectioned. The donor site of the tongue was completely closed with the 3.0 resorbable suture after separation, reintegrating the muscle mass to prevent a deformity of the postoperative tongue.

Patients received postoperative medication amoxicillin/ clavulanic acid 875/125 mg VO and ketoprofen $100 \mathrm{mgVO}$. The diet in the postoperative period was liquid the first 5 days, then a soft diet was started. He kept strict oral hygiene and rinses of chlorhexidine gluconate. Immediate postoperative care: 1) maintain a liquid diet until separation of the pedicled, 2) limitation of speech; 3) use of bandages or maxillomandibular fixation to limit the opening of the mouth, if necessary (no patient collaboration); 4) maintain oral hygiene; 5) use of aspirin (antiplatelet or platelet antiplatelet) as an adjunct to flap vascularization.

\section{RESULTS}

The original cleft palate defects were: 10 patients with unilateral lip cleft with palatal cleft, 4 patients with bilateral cleft lip with palatal cleft, and 6 patients with isolated cleft palate. The follow-up period ranged between 4 months and 24 months (Figure 6). The time spent intraoperatively presented an average of approximately 80 minutes, without complications.

Pain intensity was evaluated by the visual analog scale (VAS) that analyzes pain from 0 to 10 points where values from 1 to 3 indicate soft to moderate pain, from 4 to 6 moderate to severe pain, and more than 6 very intense, resulting in an average of 3.3 in this study, being in the range of pain from mild to moderate, with a standard deviation of 1.42 , grouping the

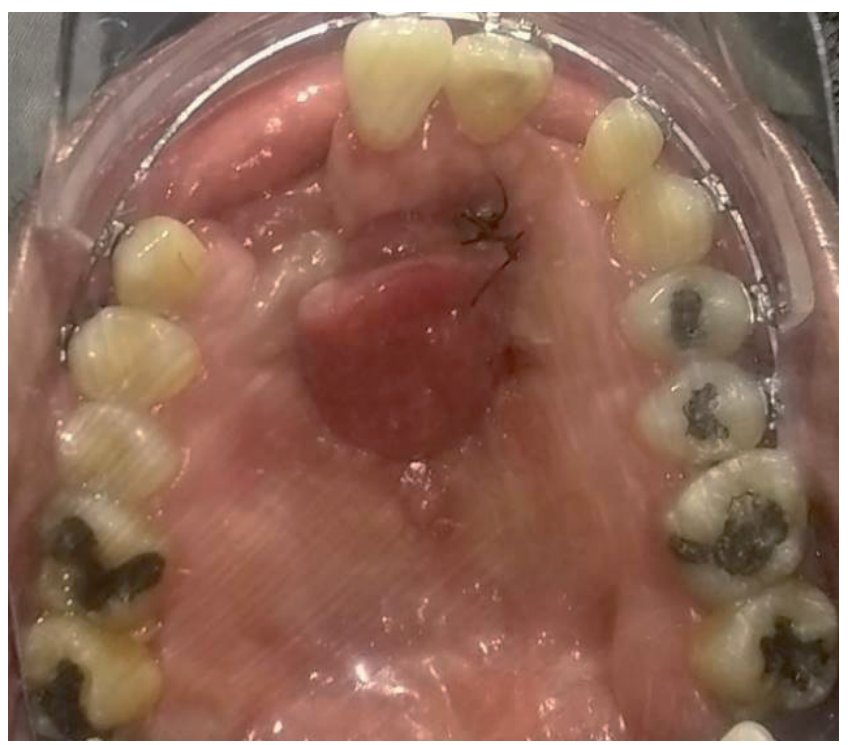

Figure 6. Late postoperative. 
Table I. Demographic information of the patients

\begin{tabular}{|c|c|c|c|c|c|}
\hline Patient A & Sex & Age & Size of Fistula & Type of Cleft* & $\begin{array}{l}\text { No. of Previous Attempts of } \\
\text { Fistula Closure }\end{array}$ \\
\hline 1 & $\mathrm{~F}$ & 26 & $9 \times 14 \mathrm{~cm}$ & UCCLP & 1 \\
\hline 2 & $\mathrm{~F}$ & 30 & $10 \times 15 \mathrm{~cm}$ & BCCLP & 1 \\
\hline 3 & M & 25 & $9 \times 12 \mathrm{~cm}$ & BCCLP & 1 \\
\hline 4 & F & 25 & $10 \times 16 \mathrm{~cm}$ & UCCLP & 2 \\
\hline 5 & M & 33 & $11 \times 14 \mathrm{~cm}$ & UCCLP & 1 \\
\hline 6 & $\mathrm{~F}$ & 37 & $8 \times 12 \mathrm{~cm}$ & BCCLP & 2 \\
\hline 7 & M & 40 & $9 \times 14 \mathrm{~cm}$ & BCCLP & 2 \\
\hline 8 & $\mathrm{~F}$ & 28 & $9 \times 12 \mathrm{~cm}$ & UCCLP & 1 \\
\hline 9 & M & 27 & $10 \times 15 \mathrm{~cm}$ & BCCLP & 1 \\
\hline 10 & $\mathrm{~F}$ & 28 & $9 \times 13 \mathrm{~cm}$ & UCCLP & 1 \\
\hline 11 & $\mathrm{~F}$ & 30 & $9 \times 14 \mathrm{~cm}$ & UCCLP & 2 \\
\hline 12 & M & 29 & $10 \times 13 \mathrm{~cm}$ & BCCLP & 1 \\
\hline 13 & M & 26 & $13 \times 19 \mathrm{~cm}$ & UCCLP & 2 \\
\hline 14 & M & 29 & $9 \times 14 \mathrm{~cm}$ & BCCLP & 2 \\
\hline 15 & M & 30 & $9 \times 12 \mathrm{~cm}$ & BCCLP & 2 \\
\hline 16 & M & 25 & $9 \times 12 \mathrm{~cm}$ & BCCLP & 1 \\
\hline 17 & $\mathrm{~F}$ & 25 & $10 \times 15 \mathrm{~cm}$ & UCCLP & 1 \\
\hline 18 & M & 25 & $13 \times 14 \mathrm{~cm}$ & UCCLP & 1 \\
\hline 19 & M & 28 & $9 \times 14 \mathrm{~cm}$ & BCCLP & 1 \\
\hline 20 & M & 33 & $10 \times 15 \mathrm{~cm}$ & UCCLP & 2 \\
\hline
\end{tabular}

${ }^{*}$ UCCLP: Unilateral Complete Cleft Lip and Palate; BCCLP: Bilateral Complete Cleft Lip and Pa.

entire study population close to its mean. A $60 \%$ of the cases (12 patients) reported soft pain, the average being 2.33 , while the remaining $40 \%$ (8 patients) showed moderate pain, with an average of 4.75 , presented during the postoperative period.

The most frequent clinical signs during the mediate postoperative period of the patients were: $60 \%$ headaches, $60 \%$ passive bleeding, $60 \%$ mild pain, $60 \%$ localized infection and $40 \%$ nasal congestion, evolving favorably with outpatient treatment. However, $40 \%$ of the patients presented partial dehiscence, so daily intraoral lavages were performed with $0.9 \%$ solution + povidine solution $+0.12 \%$ chlorhexidine irrigated with $20 \mathrm{cc}$ pressure syringes, antibiotic therapy and timely analgesic therapy, evidencing Favorable results (Table I). The Simplified Oral Hygiene Index (OHI-S) is performed preoperatively, obtaining an average of 1.0, determining that the oral hygiene of the patients is good, comparing with the evaluation of the postoperative OHI-S, reporting an average of 1.5 , maintaining good results.

Preoperative lingual motility was assessed through an observational clinical examination in a resting state, with no evidence of atrophy or fasciculations, with a central position. In a dynamic state, the patient was instructed to perform protrusion, laterality, elevation / descent movements, showing preserved movements, in the same way, an exercise with a tongue depressor (lower tongues) was performed in different positions to assess muscle strength. Said evaluations were carried out in the immediate postoperative period, dysarthria was evident, in terms of lingual motility decreased move- ments were presented and muscular strength was evident in $75 \%$ of complete muscular strength and $25 \%$ of movement against moderate resistance.

A clinical evaluation of the superficial and deep sensitivity was carried out by making contact in all the regions of the tongue with wooden applicators, toothbrush, syringe needle, with paresthesia in $30 \%$ of the patients and $70 \%$ hypoesthesia. Similarly, tests of the sense of taste were applied using different flavors: acid, sweet, salty, and even bitter, stimulating all areas of the tongue. It showed favorable evolution and satisfactory recovery during its late postoperative period (Figure 7).

In addition, acoustic voice analysis was performed through the PRAAT software; the patients in their preoperative presented average Pitch value $108,618 \mathrm{~Hz}$, in male gender and average Pitch value $119,247 \mathrm{~Hz}$, in female gender; This value was compared with the voice emissions of the patients with the 6-month late postoperative control, with an average Pitch $113,832 \mathrm{~Hz}$ in male gender and average Pitch value 132,969 $\mathrm{Hz}$ in female gender. The intonation line presented favorable changes in the postoperative period, showing continuity of the line.

\section{DISCUSSION}

Guerrero-Santos and Altamirano, were the first to report on the use of tongue flaps for closing the palatal defect ${ }^{8}$. The 


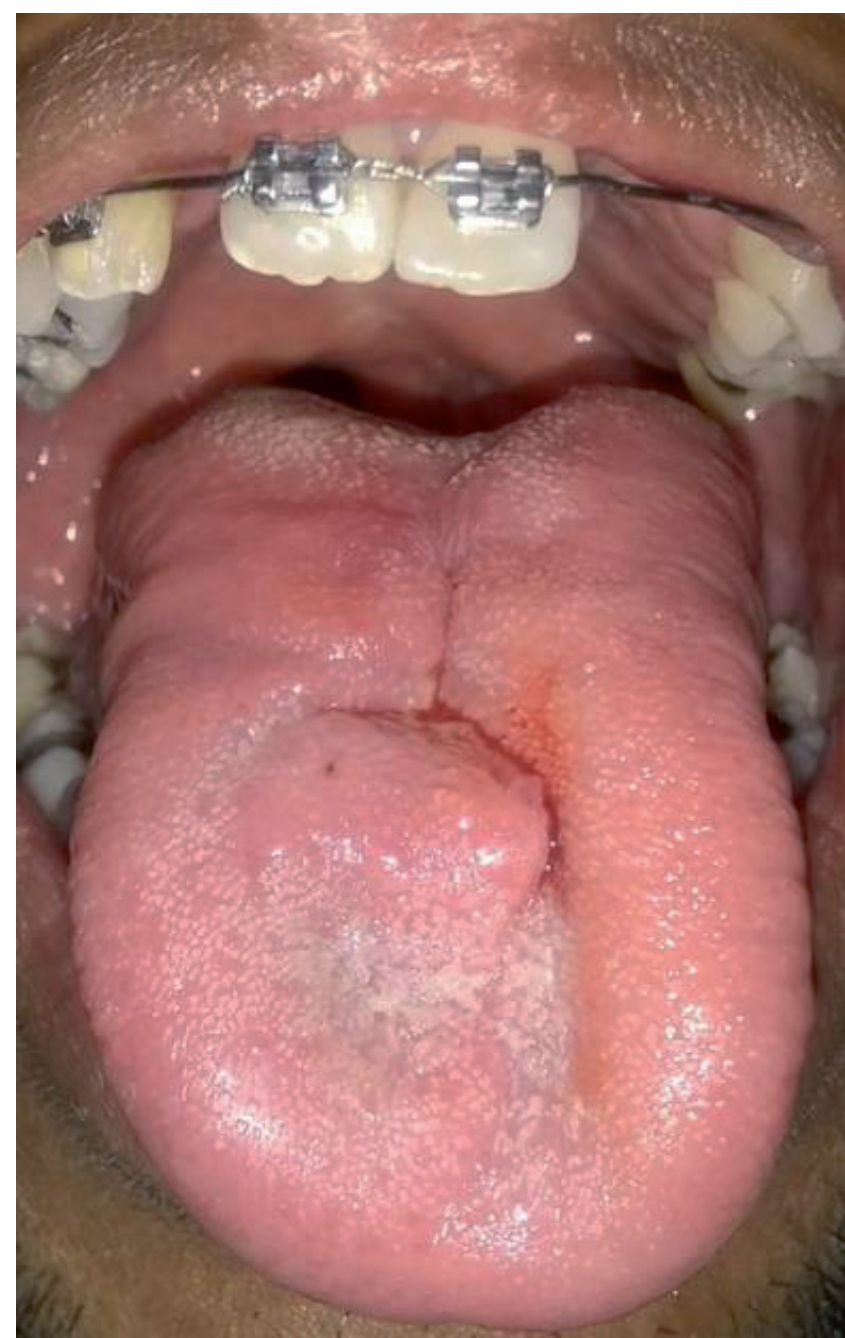

Figure 7. Postoperative tongue flap.

flap of the pediculated tongue is a reliable option for the use of complex palatal fistula closure in patients with clefts and sequelae of palatoplasty. This technique has gained great popularity for its versatility and diverse clinical applications, in addition to its large volume of tissue, as well as its excellent vascularity through the lingual artery and its branches. However, some authors suggest the use of the lingual flap only for the closure of recurrent palatal fistulas ${ }^{11}$.

It should be noted that the temporal muscle flap remains in force, making it a safe and versatile option as a pediculated reconstructive method ${ }^{12}$. However, it would be indicated in patients with extensive complex defects three-dimensionally and in those in which the lingual flap is not sufficient for closure. The greatest disadvantage of the temporal muscle is the residual aesthetic sequelae as a consequence of the temporary collapse caused.

The buccinator muscle flap represents a simple technique that is fast and relatively unaggressive. It is a very reliable flap as it has rich vascularization, and a considerable amount of muscle and mucosal tissue is supplied for repairing defects of a significant size. Nevertheless, it is not exempt of complications. The most common complication is suture dehiscence and the subsequent release of the flap, especially when it is used for the reconstruction of the hard and soft palate ${ }^{13}$. Another complication that is not so common but that is no less important, is damage to the parotid duct.

The development of microsurgical techniques has allowed carrying out post-oncological reconstruction of a greater size while solving the defects in a very anatomical way with aesthetic and functional results that are very acceptable ${ }^{14}$.

The use of tongue flaps for the closure of palatal fistulas as a sequela of palatoplasty is a safe alternative with low morbidity; Assunçao ${ }^{15}$ it reported a $100 \%$ success, confirmed other series such as Guerrero Santos and Altamirano ${ }^{8}$ where they report $70 \%$ success and Pigott et al. ${ }^{16}$, that reports $85 \%$ success in the closure of palatal fistulas by means of tongue flaps with anterior base.

Many surgeons have emphasized a double-layer closure to close a palatal fistula to ensure non-recurrence ${ }^{16-18}$. In addition, some surgeons have introduced a 3-layer closure, arguing better results ${ }^{19}$. The low recurrence rate of multi-layer closure demonstrates that the tongue flap is associated with better results compared to double-layer closure. According to Strauss et al. ${ }^{20}$, for the closure of the defect in two layers, the tongue flap can be combined with hinged mucoperiosteal flaps from the periphery of the fistula or vomer flaps to create a nasal floor and the layered closure of the fistula. In our case, the closure was carried out in two layers, conforming the nasal mucosa with peripheric mucoperiosteal flaps.

The advantages of the tongue flap include proximity to the intraoral receptor site, an excellent blood supply, a large amount of tissue it can provide, a low morbidity at the donor site and an effective reinnervation of the flap. Early complications include hemorrhage, bruising, infection, and the risk of flap detachment. Late complications include partial or total flap necrosis. Inadequate flap design, wide mouth opening and involuntary or excessive tongue movements contribute to most of these complications.

Colonel et al., after suturing the flap of the tongue in place, adapted it against the anterior part of the hard palate and was attached to the upper teeth by three sling sutures that were extracted through the body of the tongue, restricting thus the movements of the tongue. In addition, all patients were maintained with the nasogastric tube during the entire period of 21 days until the separation of the pedicle. In the study that is reported, only fixation of the pedicle to the palatal defect is made, without the need to use a nasogastric tube for its feeding 21 .

Although intermaxillary fixation (IMF) has been proposed to further restrict tongue movements ${ }^{15,21}$. Habib et al. ${ }^{22}$, in his study of 30 children who presented fistulas after palatoplasty, intermaxillary fixation was not necessary in the technique used, resulting in survival of the 30 flaps (100\%) and complete closure in all patients. This result coincides with the cases reported in this study, considering intermaxillary fixation redundant and unnecessary because of the patient's collaboration and age, and the inspection and cleaning of the oral cavity and operative site was better. It was considered to leave a long pedicle, so that the tongue can rest in its position and not be tied to the palate. This gives the tongue a little room to move and helps patients tolerate the procedure, tolerate feeding, and be able to talk. 
Several studies have revealed a high incidence of detachment of the tongue flap (up to $25 \%$ ), particularly in the early postoperative period ${ }^{23,24}$, when no modality has been used to tie the tongue ${ }^{25}$. It was also observed that the voluminous and rough appearance of the reconstructed area changed its appearance over time, became much smaller and softer, acquired an appearance very similar to that of adjacent tissues. The patients did not present a decrease of the size of the tongue, loss or change in the sensation of the taste or any difficulty in speaking and swallowing after cutting the pedicle.

\section{CONCLUSION}

The tongue flap is an excellent alternative for the closure of large or recurrent palatal fistulas due to its versatility and excellent vascularity of this anatomical, however, the design and the delicate manipulation of the flap are also determinants. The treatment of the oronasal fistula by a two-layer closure using the nasal mucoperiosteal tissue together with a dorsal pedicled tongue flap with anterior base is a reliable method with a high success rate.

\section{REFERENCES}

1. Lu Y, Shi B, Zheng Q Hu Q Wang Z. Incidence of palatal fistula after palatoplasty with levator veli palatini retropositioning according to Sommerlad. Br J Oral Maxillofac Surg. 201;48(8):63740. DOI: 10.1016/j.bjoms.2009.10.018.

2. Hardwicke JT, Landini G, Richard BM. Fistula incidence after primary cleft palate repair: a systematic review of the literature. Plast Reconstr Surg. 2014t;134(4):618e-27e. DOI: 10.1097/ PRS. 0000000000000548

3. Sadhu P. Oronasal fistula in cleft palate surgery. Indian J Plast Surg. 2009;42 Suppl:S123-8. DOI: 10.4103/0970-0358.57203.

4. Lithovius RH, Ylikontiola LP, Sándor GK. Incidence of palatal fistula formation after primary palatoplasty in northern Finland. Oral Surg Oral Med Oral Pathol Oral Radiol. 2014;118(6):6326. DOI: 10.1016/j.0000.2014.07.002.

5. Domarus HV. The double-door tongue flap for total cheek mucosa defects. Plast Reconstr Surg. 1988;80(2):351-6. DOI: 10.1097/00006534-198808000-00027.

6. Chicarilli ZN. Sliding posterior tongue flap. Plast Reconstr Surg. 1987;79(5):697-700. DOI: 10.1097/00006534-198705000-00002.

7. Smith TS, Schaberg SJ, Collins JC. Repair of a palatal defect using a dorsal pedicle tongue flap. J Oral Maxillofac Surg. 1982;40(10):670-3. DOI: 10.1016/0278-2391(82)90120-3.

8. Guerrero-Santos J, Altamirano JT. The use of lingual flaps in repair of fistulas of the hard palate. Plast Reconstr Surg. 1966;38(2):123-8. DOI: 10.1097/00006534-19660800000007.
9. Cadenat $\mathrm{H}$, Combelle R, Fabie M. Lambeaux de langue, vascularisation, morphologie et utilisation. Ann Chir Plast. 1973;18:223-7.

10. Padwa Bonnie L, Mulliken John B. Complications associated with cleft lip and palate repair. Oral Maxillofac Surg Clin North Am. 2003;15(2):285-96. DOI: 10.1016/S1042-3699(02)00103-6.

11. Ogle Orrett E. The Management of oronasal fistulas in the cleft palate patient. Oral Maxillofac Surg Clin North Am. 2002;14(4):55362. DOI: 10.1016/s1042-3699(02)00050-X.

12. Hanasono MM, Utley Ds. Goode RL. The temporalis muscle flap for reconstruction after head and neck oncologic surgery. Laryngoscope. 2001;111(10):1719-25. DOI: 10.1097/00005537200110000-00009.

13. Licameli GR, Dolan R. Buccinator musculomucosal flap: applications in intraoral reconstruction. Arch Otolaryngol Head Neck Surg. 1998;124(1):69-72. DOI: 10.1001/archotol.124.1.69.

14. Nehrer-Tairych GV, Millesi W, Schuhfried O, Rath. A comparision of the donorsite morbidity after using the prelaminated fasciomucosal flap and the fascicutaneous radial forearm flap for intraoral reconstruction. Br J Plast Surg. 2002;55:198-202. DOI: 10.1054/bjps.2002.3812.

15. Assunçao AG. The design of tongue flaps for the closure of palatal fistulas. Plast Reconstr Surg. 1993;91(5):806-10. DOI: 10.1097/00006534-199304001-00008.

16. Pigott RW, Rieger FW, Moodie AF. Tongue flap repair of cleft palate fistulae. Br J Plast Surg. 1984;37(3):285-93. DOI: 10.1016/0007-1226(84)90068-7.

17. Zeidman A, Lockshin A, Berger J, Gold B. Repair of a chronic oronasal defect with an anteriorly based tongue flap. J Oral Maxillofac Surg. 1988;46(5):412-5. DOI: 10.1016/0278-2391(88) 90228-5.

18. Coghlan K, O'Regan B, Carter J. Tongue flap repair of oronasal fistulae in cleft palate patients - A Review of 20 Patients. J Craniomaxillofac Surg. 1989;17(6):255-9. DOI: 10.1016/s10105182(89)80093-9.

19. Steinhauser EW. Experience with dorsal tongue flaps for closure of defects of harde palate. J Oral Maxillofac Surg. 1982;40(12):7879. DOI: 10.1016/0278-2391(82)90174-4.

20. Strauss RA, Kain NJ. Tongue Flaps. Oral Maxillofac Surg Clin North Am. 2014;26(3):313-25. DOI: 10.1016/j.coms.2014.05.002.

21. Colonel Priya Jeyaraj. Techniques to Improve Reliability and Predictability of the Dorsal Pedicled Tongue Flap in Closure of Palatal Defects and Oronasal Fistulae. J Maxillofac Oral Surg. 2018;17(2):175-81. DOI: 10.1007/s12663-017-1035-6.

22. Habib A, Brennan P. The Deepithelialized Dorsal Tongue Flap for Reconstruction of Anterior Palatal Fistulae: Literature Review and Presentation of Our Experience in Egypt. Cleft Palate Craniofac J. 2016;53(5):589-96. DOI: 10.1597/15-017.

23. Awang MN. Closure of oroantral fistula. Int J Oral Maxillofac Surg. 1988;17(2):110-5. DOI: 10.1016/s0901-5027(88)80162-0.

24. Kuran I, Sadiko_glu B, Turan T, Hacikerim S. The sandwich technique for closure of a palatal fistula. Ann Plast Surg. 2000;45(4):4347. DOI: $10.1097 / 00000637-200045040-00015$.

25. Vasishta SMS, Krishnan G, Rai YS, Desai A. The versatility of the tongue flap in the closure of palatal fistula. Craniomaxillofac Trauma Reconstr. 2012;5(3):145-60. DOI: 10.1055/s-0032-1313352. 